\title{
GEOLOGIC MAP AND SECTIONS OF THE HOLY CROSS QUADRANGLE, EAGLE, LAKE, PITKIN, AND SUMMIT COUNTIES, COLORADO
}

\author{
Miscellaneous Investigations Series Map I-830 \\ By Ogden Tweto \\ 1974
}

Sheet 1 of 2

Geology of eastern half mapped by Ogden Tweto, 1948-53; western half mapped by Ogden Tweto and R.C. Pearson, 1954-59

Base from U.S. Geological Survey 1:62,000 1949

10,000-foot grid based on Colorado coordinate system, central zone

Scale 1:24,000

Contour interval 50 feet

Datum is Mean Sea Level

\section{Sheet 2 of 2}

Sheet 2 contains the following illustration:

INDEX MAP OF TOPOGRAPHIC QUADRANGLES, MAJOR GEOGRAPHIC FEATURES, AND GEOLOGIC MAP AREAS IN AND BORDERING THE HOLY CROSS QUADRANGLE. MAP AREAS:

1. Minturn quadrangle: Lovering and Tweto (1944).

2. Gore Range-Eagles Nest Primitive Area: Tweto, Bryant, and Williams (1970).

3. Southwest quarter of Dillon quadrangle: Bergendahl (1969).

4. Pando area: Tweto (1953).

5. Tennessee Pass area: Tweto (1956).

6. Kokomo-Tenmile district: Bergendahl and Koschmann (1971).

7. Sugar Loaf-St. Kevin districts: Singewald (1955).

8. Leadville district: Emmons, Irving, and Loughlin (1927).

9. West slope of Mosquito Range: Behre (1953).

10. Leadville 30-minute quadrangle: Tweto and Case (1972).

Horizontal and vertical scales 4 times map scale.

Scale 1:24,000

Datum is Mean Sea Level

Cross sections $A-A^{\prime}, B-B^{\prime}, C-C^{\prime}, D-D^{\prime}, E-E^{\prime}$

$D-D$ ' and $E-E$ 'note: Section constructed from detailed manuscript map of Leadville area, scale 1:48,000, from which geology in southeast corner of quadrangle map was generalized. For data on named faults and shafts see U.S. Geol. Survey Prof. Paper 148 (1927).

See sheet 1 for geologic map

Note: For cross sections of northeastern and east-central parts of quadrangle see Tweto (1953 and 1956).

\section{DESCRIPTION OF MAP UNITS}

Qdr

RECENT MORAINES (HOLOCENE) — Neoglacial moraines, rockstream deposits of glacial origin, and rubble overlying perennial ice

Qag ALLUVIUM AND GRAVELS (HOLOCENE AND PLEISTOCENE) - Stream alluvium, alluvial-fan deposits, terrace gravels, glacial-lake gravels, and bog deposits. Locally grade into Qlt unit 
LANDSLIDE DEBRIS AND TALUS (HOLOCENE AND PLEISTOCENE)—Landslide, talus, avalanche, and periglacial boulder-creep deposits; glacial and postglacial in age

Qd GLACIAL DRIFT (HOLOCENE AND PLEISTOCENE) - Drift of two glacial advances of Bull Lake age and three younger advances of Pinedale age. Unit consists mainly of boulder till but includes stratified deposits incorporated in moraines; moraines of Pinedale age generally more bouldery at surface than those of Bull Lake age. Bull Lake deposits typically form prominent high lateral moraines and massive terminal moraines, some of which are extensively dissected. Moraines of first Pinedale glacial advance generally are nearly coextensive with Bull Lake moraines but smaller in volume; small moraines of the two later Pinedale advances are in the canyon bottoms upstream from the older terminal moraines

QI LOESS (PLEISTOCENE) - Windblown silt, mainly of Bull Lake age. Mapped only north of Tennessee Pass on slope between Fiddler Creek and Taylor Gulch where it overlies pre-Bull Lake drift, intertongues with Bull Lake moraine of Bennett Gulch, and is extensively mantled by slopewash consisting of porphyries and rocks of Minturn Formation. Shafts show thickness of as much as 75 feet. Silt probably was derived from outwash deposits that fill the lower valley of Mitchell Creek to the west

Qdpb GLACIAL DRIFT (PLEISTOCENE) — Drift of two glaciations of pre-Bull Lake age. These two glaciations were separated by a period of pedimentation. Till of earlier glaciation is in blanketlike bodies without morainal form. Top of this till is weathered to tough clayey red-brown gumbo in which only the highly siliceous clasts remain firm. Gumbo was irregularly eroded prior to succeeding glaciation and is absent in places. As shown by shafts in Leadville area, gumbo is as much as 50 feet thick and grades downward into fresh till. Large body of this old till underlies Arkansas valley from Tennessee Pass southward to quadrangle boundary. Younger pre-Bull Lake till is mainly in highly modified—nearly blanketlike - morainal remnants on canyon sides above the Bull Lake lateral moraines. These have few or no boulders exposed at surface. Till is typically buff to light brown and clayey to depths of $10-30$ feet; below this it is light gray and sandy

Qm MALTA GRAVEL (PLEISTOCENE) - Coarse, poorly sorted, poorly stratified gravel; as much as 300 feet thick at Leadville. Consists of a copious outwash gravel of the second pre-Bull Lake glaciation and of contemporary stream, alluvial fan, and colluvial deposits of nonglacial origin. At Leadville, original constructional surfaces are pedimentlike but are to be distinguished from the true pediments farther south, which are cut over the oldest glacial drift and the Dry Union Formation. Malta Gravel is preserved only in the Arkansas River valley, and its source was principally from the east side of the valley

QTe

PREGLACIAL COLLUVIUM (PLEISTOCENE OR PLIOCENE) - Bouldery to gravelly colluvium and alluvium preserved in a few small patches in gulches or on dipslopes on lower flank of Sawatch Range above the level reached by glaciers in Eagle River valley

Tdu DRY UNION FORMATION (PLIOCENE AND MIOCENE) - Shown on cross sections only. Predominantly brown sandy and pebbly silt but contains lenses of gray to white sand, greenish- and pinkish-gray clay, and brownish-gray gravels, and thin beds of light-colored volcanic ash. Silt is coherent enough to fracture in angular blocks but is not cemented; sand and gravel are generally somewhat cemented, and some gravel is cemented to hard conglomerate by calcium carbonate of fossil caliche zones. Dry Union is not exposed at surface within quadrangle but underlies Arkansas valley and parts of Leadville district as shown in cross sections. Preserved thickness near Leadville is less than 1,000 feet; a few miles to the southwest it may reach 3,000-4,000 feet (Tweto and Case, 1972). Vertebrate fossils found in the Salida area date the Dry Union as Pliocene and Miocene in age (G. E. Lewis, U.S. Geological Survey, oral commun., 1972). At Leadville, as shown from subsurface data (sections $D-D^{\prime}$ and $E-E^{\prime}$, and areas beyond quadrangle boundaries), the Dry Union is displaced by many faults and thus serves to document late movements on these faults

Tir INTRUSIVE RHYOLITE (PLIOCENE OR MIOCENE) - Fine-grained white rhyolite and light-gray to black flowbanded vitrophyre. Occurs in north-trending dike system on flank of Sawatch Range, from south edge of quadrangle to north side of Longs Gulch, and in scattered small dikes elsewhere. This rhyolite and the rhyolite breccia at Leadville are youngest intrusive rocks recognized in quadrangle. Age as young as Pliocene or late Miocene is inferred from evidence of intrusion at very shallow depth, as indicated by extensive development of virtrophyre

Trb RHYOLITE BRECCIA (PLIOCENE OR MIOCENE) - Occurs in irregular pipe in extreme southeast corner of quadrangle. Pipe is known as the Eureka pipe, and is one of four pipes known from mine workings in north-central part of Leadville district (Emmons and others, 1927). The pipes consist of rock fragments of many kinds in a matrix of altered fine-grained rhyolite. Eureka pipe contains fewer foreign fragments and is less altered than the other pipes; some of dikes branching from it are essentially uncontaminated and are indistinguishable from the intrusive rhyolite (Tir). Pipes postdate oxidation of the ore deposits which occurred in Miocene time prior to deposition of the Dry Union Formation (Tweto, 1968)

Trp RHYOLITE PORPHYRY (OLIGOCENE) - Pale-orange-pink to pale-yellowish-brown rhyolite porphyry; consists of 30-40 percent of phenocrysts and 60-70 percent of aphanitic groundmass. Quartz is most abundant phenocryst; crystals are rhombic to nearly square in cross section and $1-7 \mathrm{~mm}$ in diameter. White sanidine and pale-orange potassium feldspar crystals are $3-8 \mathrm{~mm}$ in diameter. Biotite is sparse; in plates and thin books $1 / 2-3 \mathrm{~mm}$ in diameter. Rhyolite porphyry 
occurs principally in thick subconcordant bodies along East Fork of Eagle River, in east-central part of quadrangle. The porphyry is nearly identical chemically to the Chalk Mountain Rhyolite, 2 miles east of the quadrangle, and though different in appearance, is correlated with the Chalk Mountain. The radiometric (K-Ar) age of the Chalk Mountain is 29 m.y. (Oligocene) (V. E. Surface, Climax Molybdenum Company, written commun., 1970). On earlier maps, the rhyolite porphyry was erroneously assigned to the Sacramento Porphyry (Tweto, 1956) and to the Lincoln Porphyry (Tweto, 1953)

TIb LATITE BRECCIA (OLIGOCENE) - Occurs in poorly exposed elongate body near Timberline Lake, in southwest part of quadrangle. Surface exposures are in part a breccia of boulders and cobbles of Precambrian rocks in matrix of finegrained highly altered latite or quartz latite porphyry, and in part the porphyry alone. Porphyry is pyritized; iron oxide derived from the pyrite is widely evident in spring and bog deposits in area. Exploration drilling showed porphyry to be texturally varied and consistently altered at depth. Alteration and mineralization are not evident in surrounding Precambrian rocks and are inferred to be related in origin to the porphyry body itself. Sericite from core of a drill hole in the altered rock yielded a K-Ar age of $35.4 \pm 1.2$ m.y. as determined by Geochron Laboratories for Bear Creek Mining Company (Gregory E. McKelvey, written commun., 1972)

Ter EAGLE RIVER PORPHYRY (PALEOCENE?) — Greenish-gray granodiorite porphyry composed of abundant phenocrysts of feldspars, quartz, and biotite in a finely crystalline matrix. Quartz phenocrysts are rounded grains 5-6 mm in diameter and slightly smaller rhombic crystals almost square in cross section. Most of feldspar crystals are nearly equant, 4-8 mm in diameter, but a few glassy plagioclase crystals are tabular. Eagle River Porphyry occurs principally in sills in area between East Fork of Eagle River and East Tennessee Creek. The porphyry is older than the rhyolite porphyry and younger than Lincoln Porphyry. It resembles the Lincoln and older porphyries in composition and in occurrence as widely extensive sills; therefore, it is inferred to be a member of the Cretaceous and Paleocene intrusive sequence and is classed as Paleocene(?) in age

Thl HORNBLENDE LATITE PORPHYRY (PALEOCENE?) - Pinkish-gray to dark-gray granodiorite porphyry characterized by abundant phenocrysts of hornblende and pink albite in gray aphanitic matrix. Mapped only in dikes and small connecting sills on south slope of Mount Zion, but observed also on dumps of caved mine workings on East Tennessee Creek. Cuts Lincoln Porphyry; on basis of composition is inferred to be of about same age as Eagle River Porphyry

LINCOLN PORPHYRY (PALEOCENE) - Light-gray to light-bluish-gray quartz monzonite porphyry. Distinguished from other porphyries by presence of abundant large $(2-5 \mathrm{~cm})$ orthoclase phenocrysts and, in many places, by quartz in rounded bipyramids $5-15 \mathrm{~mm}$ in diameter. These large phenocrysts are in a porphyritic matrix composed of white anhedral to subhedral plagioclase crystals $2-5 \mathrm{~mm}$ in diameter, small quartz and orthoclase grains, and abundant small biotite flakes and books, all set in a bluish-gray aphanitic groundmass. Lincoln Porphyry occurs in sills, dikes, and crudely laccolithic bodies; it is one of most abundant and widespread porphyries in quadrangle and region. It was emplaced late in the period of Laramide fault development; thus it cuts faults, and many of the dikes follow faults. In most occurrences, the Lincoln is strongly altered deuterically, as are almost all the porphyries. A fresh sample yielded a K-Ar age of 64 m.y. (Pearson and others, 1962), indicating a very early Paleocene age

TKj JOHNSON GULCH PORPHYRY (PALEOCENE OR UPPER CRETACEOUS) - Gray to bluish-gray quartz monzonite porphyry. Similar to Lincoln Porphyry except that rounded bipyramids of quartz are not as large, and contains only widely scattered large $(1-2 \mathrm{~cm}$ ) orthoclase phenocrysts (one per sq ft to one per sq yd). Johnson Gulch is one of the two principal porphyries at Leadville, and it may be an approximate counterpart of Lincoln Porphyry, which is absent in most of Leadville district. However, dumps of two prospect tunnels in Johnson Gulch Porphyry in northern part of district contain small areas of Lincoln Porphyry, suggesting that dikes of Lincoln were encountered in the Johnson Gulch. Attempts to date the Johnson Gulch isotopically were unsuccessful because of ubiquitous alteration of biotite (Pearson and others, 1962)

TKsd SYENITE AND DIORITE (PALEOCENE OR UPPER CRETACEOUS) — Pinkish-gray equigranular syenite and intergrading dark-gray dioritic facies. Syenite consists principally of perthitic potassium feldspar and hornblende; grades into diorite by increase in hornblende and plagioclase. Occurs in dikes and small irregular bodies near the south-central part of east boundary of quadrangle, and eastward. Relations to faults similar to those of Lincoln Porphyry, but is cut by Lincoln Porphyry

TKe ELK MOUNTAIN PORPHYRY (PALEOCENE OR UPPER CRETACEOUS) - Gray to bluish-gray quartz monzonite porphyry. Abundant phenocrysts of quartz, feldspars, and biotite in aphanitic groundmass. Quartz in scattered rounded grains 4-8 $\mathrm{mm}$ in diameter and in more abundant 1-3 mm rounded bipyramids; potassium feldspar is yellow white to pale orange, in 4-8 mm grains; plagioclase is abundant, in white subhedral grains 1-3 mm in diameter; abundant biotite in $1 / 2-1 \mathrm{~mm}$ flakes and in scattered larger books or prisms. The Elk Mountain Porphyry occurs mainly in sills and is the principal porphyry of northeastern part of quadrangle and the Kokomo area to east, described by Bergendahl and Koschmann (1971)

TKS SACRAMENTO PORPHYRY (PALEOCENE OR UPPER CRETACEOUS) - Medium-gray granodiorite porphyry composed of abundant phenocrysts in finely crystalline groundmass. Phenocrysts are mainly white feldspars in anhedral grains 2-4 $\mathrm{mm}$ in diameter, and abundant small flakes of biotite; hornblende and occasional augite phenocrysts are also 
present in most localities. Quartz phenocryst content is variable; abundant rounded to bipyramidal grains in some localities, and only scattered grains in others. Sacramento occurs in thick domed sill along west side of Mount Zion and in thick sills east of southern part of quadrangle. It is cut by Lincoln, Eagle River, and hornblende latite porphyries, and it cuts Pando Porphyry

Kp PANDO PORPHYRY (UPPER CRETACEOUS) - Light-yellow to white fine-grained quartz latite porphyry. Typical Pando is deuterically altered aphanitic rock that contains sparse small phenocrysts of altered plagioclase and biotite, and scattered quartz grains in rounded bipyramids; locally, thin books of smoky muscovite and equant crystals of pale-orange potassium feldspar are present in small amounts. Remnant of unaltered rock in small pluton north of Leadville is nearly equigranular, finely crystalline. Pando Porphyry occurs in widespread sills, sublaccolithic bodies, a few dikes, and a small stock with concordant roof. Regionally, it is the most voluminous and widespread of all the porphyries. It includes both the "White porphyry" and "Mount Zion porphyry" of former usage at Leadville. Pando is also the earliest of the porphyries in the eastern part of Holy Cross quadrangle and Mosquito Range to the east. Age by K-Ar method is 70 m.y. (Pearson and others, 1962). Pando was emplaced early in period of Laramide fault development (Tweto, 1960). Pando probably is shallow-environment equivalent of granodiorite $(\mathrm{Kg})$ in Sawatch Range and of Buckskin stock in Mosquito Range

Kg GRANODIORITE (UPPER CRETACEOUS)-Fine-grained medium-gray biotite-hornblende granodiorite. Occurs in small elongate stock near Missouri Creek and in a smaller stock at West Tennessee Lakes, in Precambrian terrane of Sawatch Range. Missouri Creek stock is generally concordant with Precambrian gneisses, and in places near the stock, granodiorite invaded gneisses lit-par-lit. This stock probably extends northwestward beneath Precambrian rocks, because gneisses for distance of more than 3 miles give anomalously low K-Ar ages. Radiometric age of granodiorite is 70 m.y. (Pearson and others, 1962). Granodiorite closely resembles that of Buckskin stock in Mosquito Range (Singewald, 1932; Kuntz, 1968) and is similar chemically. Grandiorite of Buckskin stock also invaded Precambrian gneisses lit-par-lit

TKu UNCLASSIFIED PORPHYRIES (TERTIARY AND UPPER CRETACEOUS)—Miscellaneous unclassified porphyry dikes, mainly in Precambrian terrane

Pm MINTURN FORMATION (MIDDLE PENNSYLVANIAN) - Arkosic grit, conglomerate, shale, and sandstone in lenticular bodies, and intercalated beds and reefs of dolomite and limestone. Predominantly gray but dull maroon near base, and maroon to brick-red above Robinson Limestone Member. About 6,000 feet thick, but only 5,000 feet preserved in quadrangle_-in northeast corner (Tweto, 1949, 1953)

Pmwq White Quail Limestone Member-Dark-gray oolitic limestone and small lenses of black dolomite; locally grades into black dolomitic shale. Contains fossils of Des Moines age. About 10 feet thick. Lies about 5,000 feet above base of formation

Pme Elk Ridge Limestone Member - Gray, or mottled pink and gray limestone; contains sandy streaks and is locally oolitic. 7-12 feet thick. Lies about 4,800 feet above base of formation

Pmrl Robinson Limestone Member-Sequence of 4-6 beds of gray, light-blue-gray-weathering limestone and intervening clastic rocks. Individual limestone beds - indicated by dark blue lines - are 5-30 feet thick; contain fossils of Des Moines age. Member is 300-400 feet thick. Its base is about 4,200 feet above base of Minturn Formation

Pmr Resolution Dolomite Member-Light- to dark-gray fine-grained dolomite in single bed or in sequence of two or three beds separated by crossbedded clastic rocks in lenses 5-50 feet thick. Individual dolomite beds are typically about 15 feet thick but swell in places to 40 feet. Base of member is about 3,700 feet above base of Minturn

Pmh Hornsilver Dolomite Member-Light-weathering gray dolomite bed 20-30 feet thick; distinctive in appearance because lower two-thirds is massive and upper part is thin bedded. On Hornsilver Mountain merges into dolomite reef that also has other, less persistent, dolomite beds branching from it. About 2,900 feet above base of formation

Pmw Wearyman Dolomite Member-Massive, light-gray to yellowish-gray, porous, crystalline, reef dolomite. Consists of coalescing algal domes, and pinches and swells from 15 to 75 feet thick. About 2,600 feet above base of Minturn

Jack 8 bed of local usage - Mottled red, green, and buff bed of coarse-grained, vuggy dolomite that contains abundant varicolored chert or jasperoid. 2-5 feet thick. About 500 feet above base of Minturn in Resolution Creek area. Similar material above intrusive bodies in Chicago Ridge area may be at higher stratigraphic level

Dolomite bed or reef

Limestone bed

BELDEN FORMATION (MIDDLE PENNSYLVANIAN) - Interbedded gray to black shale and thin-bedded dark limestone and sandstone. About 200 feet thick near north edge of quadrangle; thins southeastward and then thickens again at Leadville. Intruded by sills almost everywhere; sills assimilated or mobilized shales in the Belden, causing a general thinning as well as many local variations in thickness, and a residual concentration of sandstone. Fossils in type section at Gilman, 2 miles north of quadrangle, are of Atoka age. Yellow to brown regolithic cherty silt and clay of Pennsylvanian Molas Formation is present in places beneath the Belden and was mapped with Belden. This material lies on uneven karst erosional surface at top of underlying Leadville Dolomite; generally only a few inches to a few feet thick, but as much as 50 feet in local sinkholes in karst surface 
LEADVILLE DOLOMITE (LOWER MISSISSIPPIAN) - Massive gray to blue-black dolomite and a basal sandy unit. Irregularities in thickness of Leadville are caused by uneven erosion below karst surface; in Leadville district this surface locally extends down to Gilman Sandstone Member. Leadville Dolomite is the principal host rock of ore deposits at Leadville and neighboring lead-zinc-silver districts. Total thickness 12-150 feet

Dolomite member - Upper part is gray, noncherty, and in many places was hydrothermally altered to coarse-grained, porous facies. Lower 75-80 feet is black, finely crystalline, cherty dolomite. Shown in sections $D-D$ ' and $E-E$ ' only. $0-120$ feet thick

Mlg Gilman Sandstone Member-Gray to yellow-gray sandstone, sandy and cherty dolomite, and chert breccia in lenticular beds. Shown in sections $D$ - $D^{\prime}$ and $E$ - $E^{\prime}$ only. 12-30 feet thick

De CHAFFEE FORMATION (UPPER DEVONIAN) - Consists of two dissimilar members: the Dyer Dolomite, 60-90 feet thick, and underlying Parting Quartzite, 25-60 feet thick. These members are distinguished locally on map, and in sections $D-D^{\prime}$ and $E-E$ '

Ded Dyer Dolomite Member-Thin-bedded dark-gray to black dolomite; weathers light yellow gray in upper part. Contact with Parting Member is sharp in most places but locally is gradational. Dyer is an important host rock of ore deposits at Leadville; it and Leadville Dolomite constitute the "Blue limestone" of old usage at Leadville

Dep Parting Quartzite Member-White to tan crossbedded coarse-grained quartzite and quartz-pebble conglomerate. At Leadville, a few feet of red, green, and purple shale at base. Lies unconformably on Manitou Dolomite in south half of quadrangle, and on Harding, Manitou, or Peerless in north half

Oh HARDING SANDSTONE (MIDDLE ORDOVICIAN)-Discontinuous thin unit between unconformities. In some places, consists of only a few feet of purple, green, and yellow shale, gritty mudstone, and sandstone. Where thicker, green-gray sandstone predominates in lower part; in canyon north of Pando, lower part is white quartzite in lenses filling channels cut into underlying Peerless Formation. Maximum thickness 40 feet. Absent south of Tennessee Pass

Om MANITOU DOLOMITE (LOWER ORDOVICIAN) - White to gray medium-bedded crystalline dolomite; contains irregularly distributed white chert; weathers brown, with rough and sharp surfaces caused by minute siliceous veinlets that stand out in relief. At Leadville, 115 feet thick; thins northward to Tennessee Pass beneath erosional unconformity at base of overlying Chaffee Formation, and from Tennessee Pass thins northward beneath unconformity at base of overlying Harding Sandstone. Wedge edge is at south end of Eagle Park. Manitou is important host rock of ore deposits at Leadville, where it is known locally as "White limestone"

Ou

HARDING SANDSTONE AND MANITOU DOLOMITE UNDIVIDED (MIDDLE AND LOWER ORDOVICIAN)Mapped where the two units are too thin to be shown individually

€p PEERLESS FORMATION (UPPER CAMBRIAN) - Thin-bedded buff, green, and maroon sandy dolomite, dolomitic sandstone, dolomite, and dolomitic shale. In south part of quadrangle, Peerless is overlain with inconspicuous disconformity by Manitou Dolomite. In north part, it is overlain in places by Harding Sandstone and in others by Parting Quartzite Member of Chaffee Formation. Contact with underlying Sawatch Quartzite is conformable and locally gradational. 75-110 feet thick except where cut by channels filled with Harding Sandstone

Es SAWATCH QUARTZITE (UPPER CAMBRIAN)—Medium-bedded fine-grained vitreous white quartzite; locally dull pink near top, and gray to tan at base; local thin lenses of quartz-granule conglomerate at base. 185 feet thick at north edge of quadrangle; thins southward through area of shear zones in underlying Precambrian rocks to about 140 feet, and then tapers gradually southward to 100 to 115 -foot thickness at Leadville. Contact surface with Precambrian is nearly planar in most places, but has gentle relief of as much as 50 feet in shear zone area near Pando

M€u

UNDIVIDED LEADVILLE DOLOMITE, CHAFFEE FORMATION, HARDING SANDSTONE, MANITOU DOLOMITE, PEERLESS FORMATION, AND SAWATCH QUARTZITE (LOWER MISSISSIPPIAN TO UPPER CAMBRIAN) - Shown on sections only

MEs Same rocks as M€u unit but including intercalated sills - Shown on section $C$ - $C$ ' only

ST. KEVIN GRANITE UNDIVIDED (PRECAMBRIAN) - Mixtures of granite facies listed below, or unclassified St. Kevin Granite. St. Kevin forms batholith about 25 miles long and 12 miles wide in Sawatch Range (Tweto and Pearson, 1964); only the northeast part of batholith is in Holy Cross quadrangle. Batholith is characterized by many textural facies, intricate boundaries, and many septa or roof pendants of wallrocks. Whole-rock Rb-Sr isochron age is 1,390 \pm 60 m.y. (Pearson and others, 1966) nite microcline crystals $1 / 2-1$ inch long; fine-grained matrix of crystals is biotite gneiss, partly reconstituted gneiss, or granitic material. This is a border facies and is older than any of other facies 
METALAMPROPHYRE (PRECAMBRIAN) —-Dark-greenish-gray to black lamprophyric and andesitic dike-rocks metamorphosed to biotite amphibolites; weakly to strongly foliated parallel to dike walls. Dikes are of various widths, as much as 60 feet, and are mainly in dike swarm about 2 miles wide in central-western part of quadrangle. Dikes generally cut St. Kevin Granite, but a few seem to be cut by the granite, suggesting two ages of dikes

HORNBLENDE DIORITE (PRECAMBRIAN) - Dark-green-gray medium-fine-grained hornblende-rich diorite. Occurs in elongate pluglike body on East Fork Homestake Creek and in scattered dikes, which may not be all of same age. Older than lamprophyre and probably related to hornblendite unit

HORNBLENDITE (PRECAMBRIAN) - Greenish-black coarse-grained to very coarse grained hornblendite; contains small amounts of phlogopite or biotite; a few bodies contain relicts of augite and olivine, and a few contain small amounts of calcic plagioclase. Occurs mainly in pods a few tens of feet to a few hundred feet long, in or near Precambrian shear zones. Hornblendite in shear zones is not sheared, suggesting that it is younger than the shearing, but the possibility exists that this very tough rock predates and survived at least some of the shearing

GRANITIC AND DIORITIC ROCKS OF HOLY CROSS CITY (PRECAMBRIAN)—Suite of compositionally variable, intergrading dioritic, granodioritic, and granitic rocks, in streaks or layers generally concordant with enclosing gneisses. Age relations to other granitic and dioritic rocks not established, but intrusive habit and composition suggest relationship to granite of Cross Creek rather than to St. Kevin Granite. Cut by some shear zones but apparently terminated against others

UNCLASSIFIED GRANITES (PRECAMBRIAN) - Generally pink, texturally varied granitic rocks in small bodies in or near shear zones. In part, at least, interpreted as mobilized and recrystallized product of cataclastic rocks

ceg GRANITE OF CROSS CREEK (PRECAMBRIAN) - Medium- to coarse-grained irregularly porphyritic slightly to strongly foliated granodiorite and quartz monzonite, and related dioritic and hybrid border facies. Body in northwest corner of quadrangle is at southern edge of batholith that — north of quadrangle - probably extends eastward into Gore Range (Tweto and others, 1970). Whole-rock Rb-Sr age of granite is about 1,700 m.y. (Carl Hedge, written commun., 1969)

BIOTITE-QUARTZ DIORITE (PRECAMBRIAN) - Gray to dark-gray medium- to coarse-grained moderately to strongly foliated diorite. Inferred to be related to granite of Cross Creek

mdg MIXED MIGMATITE, DIORITE, AND GRANITIC ROCKS (PRECAMBRIAN) - Complexly mixed, structurally disorganized, poorly exposed rocks related to granite of Cross Creek

dd DIORITE DIKES (PRECAMBRIAN) - Scattered dioritic dikes of various mineralogic compositions and ages. Some probably as old as granite of Cross Creek, and some are younger than St. Kevin Granite

bg BIOTITE GNEISS AND SCHIST (PRECAMBRIAN) - Biotite-quartz-plagioclase gneiss and schist; sillimanite is present in many places, and garnet is somewhat less widespread; cordierite is present locally. The gneiss and schist are interlayered with rocks of the he unit and, along with that unit, are interpreted as largely metasedimentary in origin. No indications found of direction of stratigraphic succession

he HORNBLENDE AND CALC-SILICATE GNEISSES (PRECAMBRIAN) - Includes many varieties of interlayered biotite-poor rocks: amphibolite, hornblende-pyroxene gneiss, impure quartzites, skarn, and impure marble. Contains minor layers of biotite gneiss

mt

MIGMATITE (PRECAMBRIAN) - Thinly layered mixtures of biotite gneiss or schist and granitic materials; complexly deformed and, in part, structurally disorganized

PEGMATITE (PRECAMBRIAN) - Of several varieties and ages; some as old as migmatite and some is younger than metalamprophyre. Oldest pegmatite mapped is white, coarse-grained, and feldspathic, and has distinctive "mashed" appearance. Most of the large pegmatites in shear zones on valley wall northwest of Homestake Creek are pink and consist principally of potassium feldspar; quartz and muscovite are subordinate constituents and are erratically distributed. Many of the dikes are rhythmically banded texturally, from nearly aplitic to coarse pegmatitic. The pegmatites are undeformed or only slightly sheared and are younger than the mylonitic shear zones in which they lie. Pegmatites in and bordering the St. Kevin Granite are characterized by muscovite and by sparse black tourmaline; in a few places they contain small crystals of beryl

pEr PRECAMBRIAN ROCKS OF UNKNOWN CHARACTER - Shown only in sections and in part of area of mapped subsurface geology in Leadville district 


\section{LIST OF MAP SYMBOLS}

CONTACT — Showing dip. Solid where accurately located in sedimentary and intrusive rocks, and where approximately located or gradational in Precambrian rocks and surficial units; dashed where approximately located in sedimentary and intrusive rocks; dotted where concealed; queried where probable

FAULT - Showing dip and direction and amount of displacement, in feet. Dashed where approximately located; short dashed where followed by dike; dotted where concealed; queried where conjectural. $U$, upthrown side; $D$, downthrown side

LANDSLIP FAULT—Mostly concealed; location approximate. D, downthrown side

INFERRED CONCEALED FAULT OF ARKANSAS VALLEY GRABEN SYSTEM (Tweto, 1961; 1968; Tweto and Case, 1972) - Locations approximate or conjectural. From subsurface data and from a few exposures south of quadrangle faults are known to displace bedrock surface, strata of the concealed upper Tertiary Dry Union Formation, and some of the older Pleistocene units such as pre-Bull Lake glacial drift (Qdpb) and Malta Gravel (Qm). D, downthrown side

PRECAMBRIAN SHEAR ZONE—Showing dip. Dashed where approximately located; queried where conjectural; dotted where concealed. Broad belt of shear zones in northwestern part of quadrangle constitutes Homestake shear zone (Tweto and Sims, 1963). Curved low-dipping shear zones near Homestake Peak and head of Bennett Gulch, in west-central part of quadrangle, are elements of a Precambrian thrust-fault system. Collectively, the shear zones contain a wide variety of cataclastic rocks: blastomylonites containing large proportions of neomineralized-recrystallized minerals, phyllonites, ultramylonites, mylonites, pseudotachylite, mylonite gneisses, protomylonite, breccias, retrograded rocks, and gouge. Many individual shear zones are polycataclastic (Higgins, 1971). Shear zones pinch to very narrow movement zones or "faults" in places. In various places, shear zones are intruded by pegmatite, unclassified granite (ug), hornblendite, hornblende diorite, and metalamprophyre. Relations to various Precambrian rocks and the wide range in cataclastic products indicate long history of movements on shear zones.

Cataclastically foliated gneisses

MINOR SHEAR ZONE NOT RELATED TO HOMESTAKE SHEAR ZONE—Precambrian or younger in age

STRIKE AND DIP OF BEDS

Inclined

Vertical

STRIKE AND DIP OF FOLIATION

Horizontal

Inclined

Vertical

Inclined cataclastic foliation in shear zones

Vertical cataclastic foliation in shear zones

BEARING AND PLUNGE OF LINEATION-(May be combined with foliation symbols.)

Single

Double or multiple

Range of bearing and plunge in highly contorted and structurally disorganized rocks

Vertical

Horizontal

Vertical foliation and lineation

\section{BEARING AND PLUNGE OF SLICKENSIDES OR GROVES ON VEIN, FAULT, OR DIKE}

VEIN—Showing dip. Dashed where approximately located; dotted where concealed. Veins of Sugar Loaf district (southwest of Turquoise Lake) and St. Kevin district (Northwest of Turquoise Lake) are pyritic quartz-sulfide veins valuable chiefly for silver (Singewald, 1955). Veins of Homestake Mine near head of West Tennessee Creek are siler- and lead-bearing siderite-barite veins. Scattered veins in shear zones along Homestake Creek are mainly argentiferous galena veins, but some are copper-quartz veins. Veins of Holy Cross City area are gold-feldspar veins. Scattered veins elsewhere in Precambrian terrane are mainly quartz, with minor copper. Veins of East Tennessee Creek are siliceous gold veins in carbonate rocks. 


\section{DISSEMINATED SULFIDE MINERALS}

\section{QUARTZ REEF OR SILICIFIED ZONE}

\section{AREA OF STRONGLY ALTERED ROCKS}

MINE WORKINGS - (Omitted in Leadville district, in southeastern corner of quadrangle)

Shaft

Tunnel

Caved tunnel

Prospect pit or shallow shaft

DRILL HOLE—Depth to top of rock unit and total depth (TD) indicated in feet

BOUNDARY OF AREA NEAR LEADVILLE IN WHICH ONLY BEDROCK IS SHOWN—Geology based on data from mine workings, prospect shafts, and drill holes.

\section{SYMBOLS USED IN CROSS SECTIONS ONLY}

MINE SHAFT—Showing name; solid where in plane of section; dashed where projected less than 150 feet to plane of section

DRILL HOLE—-Showing number; projected less than 150 feet to plane of section

INTERSECTION OF SECTION WITH MINE OPENING

\section{REFERENCES}

Behre, C. H., Jr., 1953, Geology and ore deposits of the west slope of the Mosquito Range [Colorado]: U.S. Geol. Survey Prof. Paper $235,176 \mathrm{p}$.

Bergendahl, M. H., 1969, Geologic map and sections of the southwest quarter of the Dillon quadrangle, Eagle and Summit Counties, Colorado: U.S. Geol. Survey Misc. Geol. Inv. Map I-563.

Bergendahl, M. H., and Koschmann, A. H., 1971, Ore deposits of the Kokomo-Tenmile district, Colorado: U.S. Geol. Survey Prof. Paper 652, $53 \mathrm{p}$.

Emmons, S. F., Irving, J. D., and Loughlin, G. F., 1927, Geology and ore deposits of the Leadville mining district, Colorado: U.S. Geol. Survey Prof. Paper 148, 368 p.

Higgins, M. W., 1971, Cataclastic rocks: U.S. Geol. Survey Prof. Paper 687, 97 p.

Kuntz, M. A., 1968, Petrogenesis of the Buckskin Gulch intrusive complex, northern Mosquito Range, Colorado: Stanford, Calif., Stanford Univ. Ph.D. thesis, 164 p.

Lovering, T. S., and Tweto, Ogden, 1944, Geology and ore deposits of the Minturn quadrangle, Colorado: U.S. Geol. Survey open-file report, $115 \mathrm{p}$.

Pearson, R. C., Hedge, C. E., Thomas, H. H., and Stern, T. W. 1966, Geochronology of the St. Kevin Granite and neighboring Precambrian rocks, northern Sawatch Range, Colorado: Geol. Soc. America Bull., v. 77, no. 10, p. 1109-1120.

Pearson, R. C., Tweto, Ogden, Stern, T. W., and Thomas, H. H., 1962, Age of Laramide porphyries near Leadville, Colorado, in Short papers in geology and hydrology: U.S. Geol. Survey Prof. Paper 450-C, p. C78-C80.

Singewald, Q. D., 1932, Igneous history of the Buckskin Gulch stock, Colorado: Am. Jour. Sci. 5th ser., v. 24, p. $52-67$

Singewald, Q. D., 1955, Sugar Loaf and St. Kevin mining districts, Lake County, Colorado: U.S. Geol. Survey Bull. 1027-E, p. 251-299. [1956].

Tweto, Ogden, 1949, Stratigraphy of the Pando area, Eagle County, Colorado: Colorado Sci. Soc. Proc., v. 15, no. 4, p. 149-235.

Tweto, Ogden, 1953, Geologic map of the Pando area, Eagle and Summit Counties, Colorado: U.S. Geol. Survey Min. Inv. Field Studies Map MF-12 (1954).

Tweto, Ogden, 1956, Geologic map of the Tennessee Pass area, Eagle and Lake Counties, Colorado: U.S. Geol. Survey Min. Inv. Field Studies Map MF-34

Tweto, Ogden, 1960, Pre-ore age of faults at Leadville, Colorado, in Short papers in the geological sciences: U.S. Geol. Survey Prof. Paper 400-B, p. B10-B11.

Tweto, Ogden, 1961, Late Cenozoic events of the Leadville district and upper Arkansas valley, Colorado, in Short papers in the geo- 
logic and hydrologic sciences: U.S. Geol. Survey Prof. paper 424-B, p. B133-B135.

Tweto, Ogden, 1968, Leadville district, Colorado, in Ridge, J. D., ed., Ore deposits of the United States 1933-1967 (Graton-Sales Volume), v. 1: New York, Am. Inst. Mining, Metall. and Petroleum Engineers, p. 681-705.

Tweto, Ogden, Bryant, Bruce, and Williams, F. E., 1970, Mineral resources of the Gore Range-Eagles Nest Primitive Area and vicinity, Summit and Eagle Counties, Colorado: U.S. Geol. Survey Bull. 1319-C, 127 p.

Tweto, Ogden, and Case, J. E., 1972, Gravity and magnetic features as related to geology in the Leadville 30-minute quadrangle, Colorado: U.S. Geol. Survey Prof. Paper 726-C, p. C1-C31 [1973].

Tweto, Ogden, and Pearson, R. C., 1964, St. Kevin Granite, Sawatch Range, Colorado, in Short papers in geology and hydrology: U.S. Geol. Survey Prof. Paper 475-D, p. D28-D32.

Tweto, Ogden, and Sims, P. K., 1963, Precambrian ancestry of the Colorado mineral belt: Geol. Soc. America Bull., v. 74, no. 8, p. 991-1014. 